\title{
Assistance equipment refill filter water to meet drinking water needs in pondok Tahfidz Quran Al Fitrah
}

\author{
Surya Hardi ${ }^{1 *}$, Elisabeth Ginting ${ }^{1}$ \\ ${ }^{1}$ Faculty of Engineering, University Sumatera Utara, Medan, Indonesia \\ *Email: surya.hardi@usu.ac.id
}

\begin{abstract}
Water serves to transport minerals, vitamins, proteins and other nutrients throughout the body. Body temperature balance will greatly depend on water, because water is a lubricant of the body's tissues as well as pads of joints, bones, and muscles. Once the importance of water for human survival so that the availability and sustainability of water for living things must be maintained. In the life of modern society in Indonesia today, the supply of clean water to a community is usually supplied by local government-owned water companies. But due to network limitations or production capacity, often not all communities can enjoy the clean water facilities. Islamic boarding schools are religious-based educational facilities whose management is still constrained by funding problems. So the facilities are always in a limited state. As is the case with the Quran Al-Fitrah tahfidz Islamic boarding school, which is located in Namo Rambe, which has difficulty in providing clean water to be drunk at the boarding school.
\end{abstract}

Keyword: Drinking Water, Health, Islamic Boarding School

\begin{abstract}
Abstrak
Air berfungsi untuk mentransportasi mineral, vitamin, protein dan zat gizi lainnya ke seluruh tubuh. Keseimbangan suhu tubuh akan sangat tergantung pada air, karena air merupakan pelumas jaringan tubuh sekaligus bantalan sendi-sendi, tulang, dan otot. Begitu pentingnya air bagi kelangsungan hidup manusia sehingga ketersediaan dan keberlangsungan air bagi makhluk hidup harus tetap dijaga. Di dalam kehidupan masyarakat modern di Indonesia saat ini, suplai air bersih untuk suatu komunitas masyarakat biasanya dipasok oleh perusahaan-perusahaan air bersih milik pemerintah daerah. Tetapi karena keterbatasan jaringan atau kapasitas produksi seringkali tidak semua komunitas masyarakat tersebut dapat menikmati fasilitas air bersih tersebut. Pondok pesantren merupakan sarana pendidikan yang berbasis agama yang pengelolaannya masih selalu terkendala oleh masalah dana. Sehingga fasilitasnya selalu dalam keadaan terbatas. Seperti halnya pada pondok pesantren tahfidz Quran Al Fitrah, yang berada di Namo Rambe yang mengalami kesulitan dalam menyediakan fasilitas air bersih untuk dapat diminum di pondok pesantren tersebut.
\end{abstract}

Kata Kunci : Air Minum, Kesehatan, Pondok Pesantren

\section{PENDAhuluan}

Pendidikan merupakan salah satu sistem untuk memajukan Negara dalam integritas dunia dan membangun moral suatu bangsa. Salah satu sistim pendidikan Indonesia yang banyak berperan menciptakan generasi-generasi berpikiran maju adalah sistim pendidikan berbasis kepesantrenan. Sistem pendidikan pesantren ini banyak memberikan peluang dan kesempatan bagi anak bangsa dengan memberikan hal-hal positif dibanding sekolah biasa pada umumnya. Berbagai aktivitas dan peraturan yang tersusun secara kompleks dan efisien membawa para santrinya dapat menjangkau nilai-nilai moral dan integritas yang memadai. Artinya, tidak terlalu banyak waktu kosong yang terbuang seperti pendidkan formal yang tidak berasrama sehingga pemantauan terhadap anak bangsa tidak terkontrol, walaupun sebagian telah dipantau oleh orangtua masing-masing. 
Tetapi sayangnya lembaga-lembaga pendidikan pesantren banyak yang berjalan secara tertatih-tatih karena sistim pendanaan yang kurang memadai, karena biasanya sumber dana pesantren ini didapatkan dari orang-orang dari luar pesantren berupa wakaf, bukan dari para siswa seperti di sekolah umum lain. Hal ini berdampak pada kurangnya fasilitas yang memadai bagi sebuah lembaga pendidikan yang siswa atau santrinya mondok di pesantren.

Salah satunya adalah fasilitas penyediaan air minum untuk para santri. Biaya yang dikeluarkan untuk penyediaan air minum tersebut cukuplah lumayan jika dilihat dari total biaya operasional pondok. Seperti hal yang dialami oleh sebuah pondok tahfidz Quran di daerah Namo Rambe Deli Serdang yang bernama Al Fitrah, akan sangat membantu sekali jika biaya tersebut dapat dikurangi atau bahkan dapat dihilangkan sehubungan dengan mereka memiliki sebuah sumber mata air di lingkungan pondoknya tapi tidak dapat langsung diminum karena masih harus direbus sampai mendidih untuk mematikan kuman-kuman atau bakterinya agar aman untuk diminum.

Pada usulan program pengabdian pada masyarakat USU tahun 2019 ini direncanakan untuk memberikan bantuan kepada Pondok Tahfidz Quran Al Fitrah yang sangat membutuhkan unit penyaringan air baku menjadi air minum. Untuk itu tim pengabdian akan melakukan kerjasama untuk menjadikan pondok tahfidz tersebut menjadi mitra pengabdian. Pesantren ini telah berdiri sejak tahun 2017 dan memiliki kurang lebih 56 orang santri penghapal Quran. Tim pengabdian USU akan berusaha mencarikan solusi penyelesaian agar pesantren ini dapat memanfaatkan sebuah sumber mata air agar airnya dapat langsung diminum tanpa harus merebusnya.
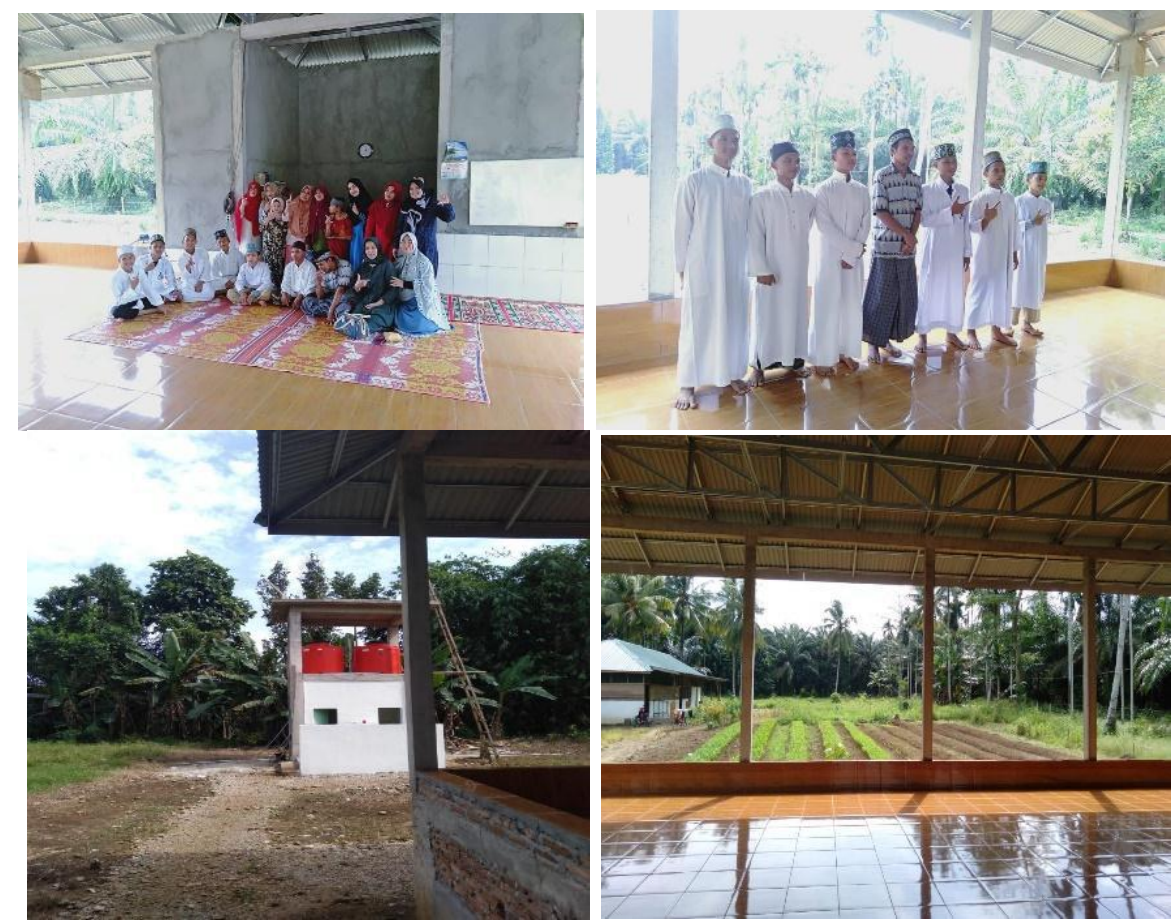

Gambar 1.1. Pondok Tahfidz Quran Al Fitrah di Namo Rambe

\section{METODE PELAKSANAAN}

Metode untuk mewujudkan kegiatan pengabdian pada masyarakat ini maka dibuatlah suatu teknik pelaksanaan agar kegiatan yang akan dilaksanakan dapat berjalan sesuai dengan jadwal, terstruktur dan tepat sasaran. Berdasarkan hal-hal di atas maka direncanakanlah suatu solusi untuk mengatasi masalah yang dihadapi mitra. Tahap pelaksanaan kegiatan dapat diuraikan sebagai berikut:

1. Melakukan survei literatur dan survei lapangan

2. Mendesain fasilitas pompa dan instalasi pemipaan air bersih 
3. Pelaksanaan pengadaan peralatan dan bahan.

4. Pelaksanaan pemasangan fasilitas pompa dan instalasi pemipaan air bersih

5. Pelaksanan pengujian sistim instalasi pompa dan pemipaan

6. Mengadakan penyuluhan mengenai penggunaan dan perawatan instalasi pompa dan pemipaan air bersih

7. Melakukan serah terima fasilitas sumber air bersih kepada mitra

8. Melakukan penulisan laporan akhir dan publikasi

Untuk mempermudah kegiatan yang dilakukan maka digunakan diagram fishbone sehingga kegiatan akan terarah dan sistematis.

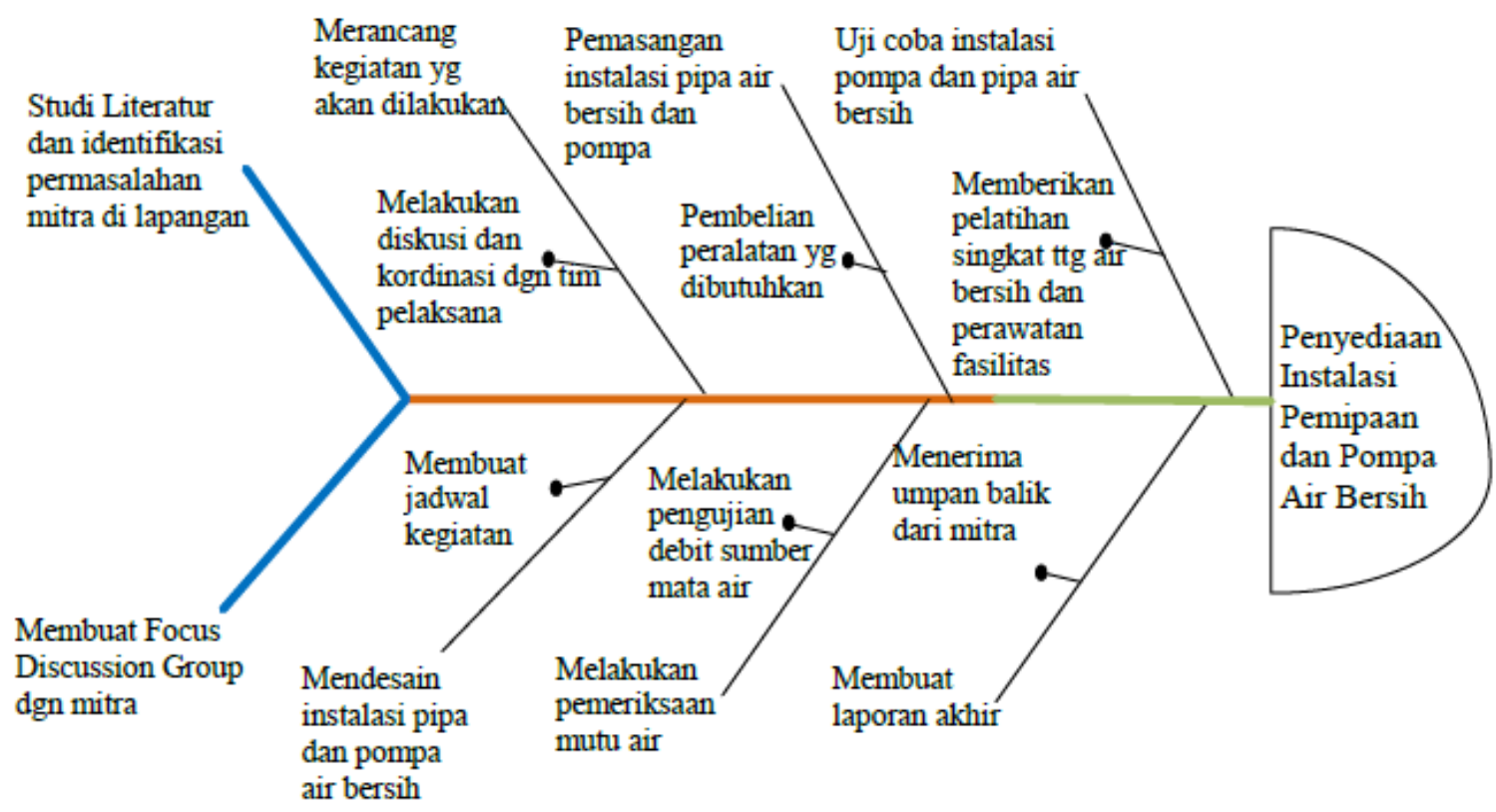

\section{Keterangan:}

Adapun kegiatan pengabdian masyarakat yang dilakukan adalah sebagai berikut:

1) Survey ke lokasi pesantren mitra

Survey ini merupakan tahapan awal kegiatan dimana pada kegiatan ini bertujuan untuk melihat secara langsung keadaan pesantren mitra, mengetahui bagaimana kondisi proses pengajarannya.

2) Identifikasi dan Perumusan Masalah.

Dari hasil survey didapat data-data tentang permasalahan yang dihadapi dan kemudian dirumuskan lalu diidentifikasikan inti permasalahan yang dihadapi mitra untuk dicarikan solusinya.

3) Penyelesaian Masalah / Solusi

Kemudian dengan cara berdiskusi bersama mitra, tim pengabdian memberikan solusi untuk menyelesaikan permasalah tersebut. Dalam hal ini solusi yang diberikan adalah memberikan bantuan.

4) Persiapan Alat 
Dari data-data yang didapat maka dilakukan penentuan spesifikasi peralatan yang diperlukan dan kemudian tim melakukan penyediaan peralatan-peralatan tersebut.

5) Instalasi Alat.

Setelah peralatan tersebut dibeli dilakukan instalasi dan setting peralatan di ruang kelas peraktek, letak peralatan juga diatur berdasarkan layout yang telah ditentukan, dan kemudian dilakukan uji coba peralatan baru.

6) Tahap Akhir.

Pada tahap ini dilakukan pelatihan tentang cara penggunaan dan perawatan peralatan kemudian dilakukan analisa terhadap unjuk kerja peralatan dan pengaruhnya terhadap kualitas pembelajarannya.

7) Publikasi Ilmiah.

Publikasi pada journal ilmiah dan media cetak/elektronik merupakan kegiatan akhir dari semua tahapan pada kegiatan ini, guna menyampaikan informasi mengenai program Iptek bagi Masyarakat.

\section{HASIL DAN PEMBAHASAN}

Jika air murni dan larutan garam dipisahkan oleh selaput semipermeabel maka akan terjadi aliran yang mengalir dari zat cair dengan konsentrasi rendah menuju ke air garam (larutan air yang mengandung kadar garam tinggi) yang mempunyai konsentrasi tinggi. Aliran air melalui selaput semipermeabel tersebut dapat berlangsung karena adanya tekanan osmosis. Jika tekanan dilakukan sebaliknya yaitu air garam diberikan suatu tekanan buatan yang besarnya sama dengan tekanan osmosis, maka yang terjadi adalah tidak ada aliran dari air ke air garam atau sebaliknya. Faktor yang mempengaruhi besar kecilnya tekanan osmosis adalah konsentrasi garam dan suhu air. Air laut umumnya mengandung TDS minimal sebesar $30.000 \mathrm{ppm}$. Sebagai contoh, untuk air laut dengan TDS $35.000 \mathrm{ppm}$ pada suhu air 25o C, mempunyai tekanan osmosis $26,7 \mathrm{~kg} / \mathrm{cm} 2$, sedangkan yang mengandung $42.000 \mathrm{ppm}$ TDS pada suhu $30 \mathrm{o}$ C mempunyai tekanan osmosis 32,7 $\mathrm{kg} / \mathrm{cm} 2$.

Jika tekanan pada sisi air garam (air asin) diberikan tekanan sehingga melampaui tekanan osmosisnya, maka yang terjadi adalah air dipaksa keluar dari larutan garam melalui selaput semipermeabel. Proses memberikan tekanan balik tersebut disebut dengan osmosis balik. Prinsip osmosis balik tersebut diterapkan untuk pengolahan air payau atau air laut menjadi air tawar. Sistem tersebut disebut Reverse Osmosis atau RO. Sistem RO tidak bisa menyaring garam sampai $100 \%$ sehingga air produksi masih sedikit mengandung garam. Untuk mendapatkan air dengan kadar garam yang kecil maka diterapkan sistem dengan dua sampai tiga saluran. Jika ingin membuat air minum yang mengandung kira-kira 300 sampai 600 ppm TDS cukup menggunakan saluran tunggal.

Jika air olahan yang dihasilkan menjadi semakin banyak maka jumlah air baku akan menjadi lebih besar dan sebagai akibatnya tekanan yang dibutuhkan akan menjadi semakin besar. Tekanan buatan (tekanan kerja) tersebut harus lebih besar dari tekanan osmosis pada air baku. Tekanan kerja yang dibutuhkan jika memakai air laut adalah antara 55 sampai $70 \mathrm{~kg} / \mathrm{cm} 2$. RO mempunyai ciri-ciri yang sangat khusus sebagai model pengolah air asin yaitu:

- Energi Yang Relatif Hemat yaitu dalam hal pemakaian energinya. Konsumsi energi alat ini relatif rendah untuk instalasi kemasan kecil adalah antara 8-9 kWh/T (TDS 35.000) dan 9-11 kWh untuk TDS 42.000.

- Hemat Ruangan. Untuk memasang alat RO dibutuhkan ruangan yang cukup hemat.

- Mudah dalam pengoperasian karena dikendalikan dengan sistem panel dan instrumen dalam sistem pengontrol dan dapat dioperasikan pada suhu kamar.

- Kemudahan dalam menambah kapasitas.

Meskipun alat pengolah air sistem RO tersebut mempunyai banyak keuntungan akan tetapi dalam pengoperasiannya harus memperhatikan petunjuk operasi. Hal ini dimaksudkan agar alat tersebut dapat digunakan secara baik dan awet. Untu menunjang operasional sistem RO diperlukan 
biaya perawatan. Biaya tersebu diperlukan antara lain untuk bahan kimia, bahan bakar, penggantian media penyaring servis dan biaya operator.

Pelaksanaan kegiatan mulai dari survei, pelaksanaan kegiatan di lapangan hingga penyelesaian laporan akhir memakan waktu selama sekitar lima bulan. Kegiatan yang dilakukan selama ini dapat diringkas sebagai berikut:

1. Survei literatur dan survei lapangan ke lokasi target

2. Menyusun rencana kegiatan

3. Mendisain fasilitas pemipaan dan pompa air bersih

4. Mempersiapkan peralatan dan bahan yang akan digunakan

5. Memasang instalasi pemipaan dan pompa air bersih dari sumber mata air ke tangki Untuk mengatasi hal

6. Melakukan pelatihan singkat tentang instalasi pemipaan air bersih dan perawatan peralatan pompa air bersih.

7. Menyusun laporan akhir

Setelah desain instalasi pemipaan dan pompa untuk mengalirkan air bersih dari sumber mata air ke toren air di lingkungan pesantren selesai dibuat, maka selanjutnya adalah memulai pekerjaan berupa penyediaan bahan-bahan yang diperlukan kemudian melakukan pekerjaan pemasangan pipa air dan pompa. Sangat dibutuhkan sekali kejelian dalam memilih jenis dan kapasitas pompa air yang digunakan karena lokasi sumber air berada jauh dilembah bukit dengan jarak 120 meter dan perbedaan elevasi dengan toren air sekitar 30 meter. Untuk mengatasi hal tersebut, setelah memperhitungkan aspek teknis dan berbagai hal maka diambil langkah dengan menggunakan 2 buah pompa, 1 unit dengan jenis jetpump dan yang satunya dari jenis pompa sentrifugal biasa. Berikut ini dapat dilihat foto-foto dokumentasi pekerjaan dan kegiatan pengabdian pada masyarakat.

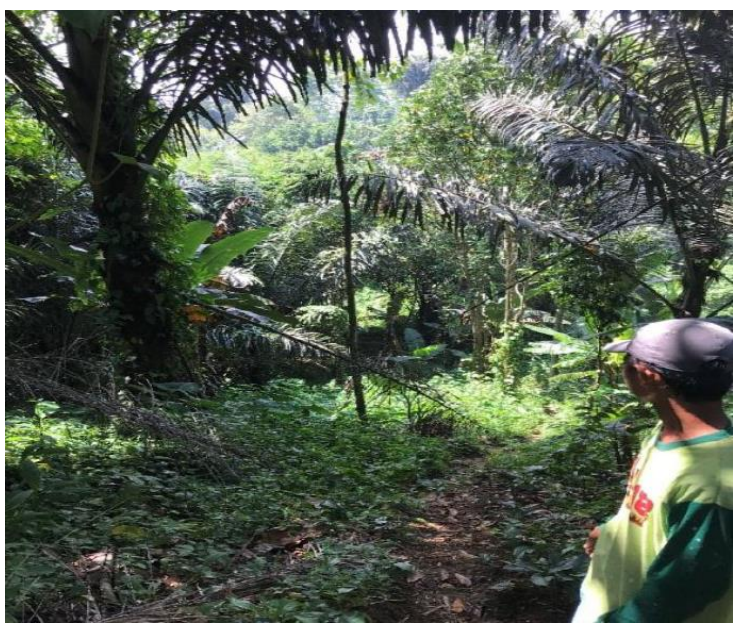

Gambar 3.1. Foto lokasi sumber mata air 


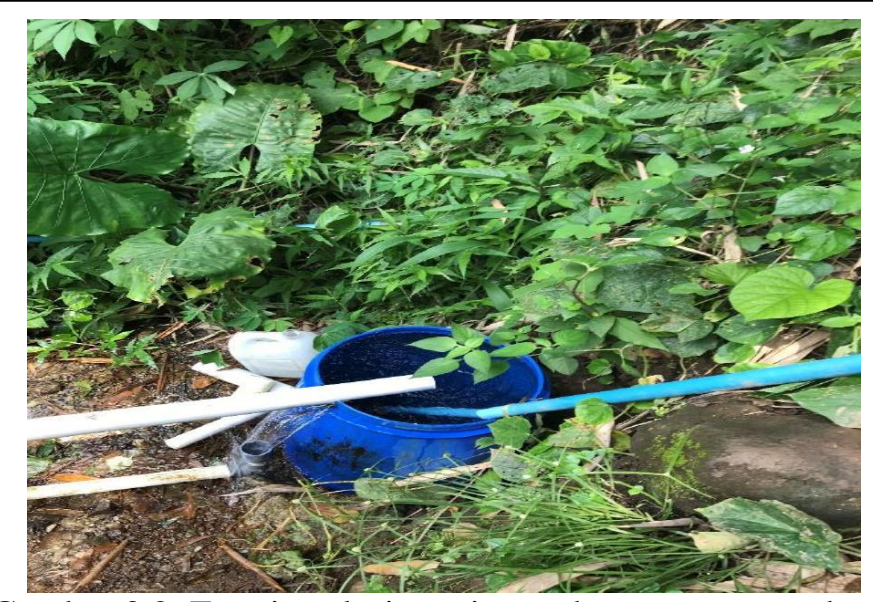

Gambar 3.2. Foto instalasi pemipaan dan pompa yang lama

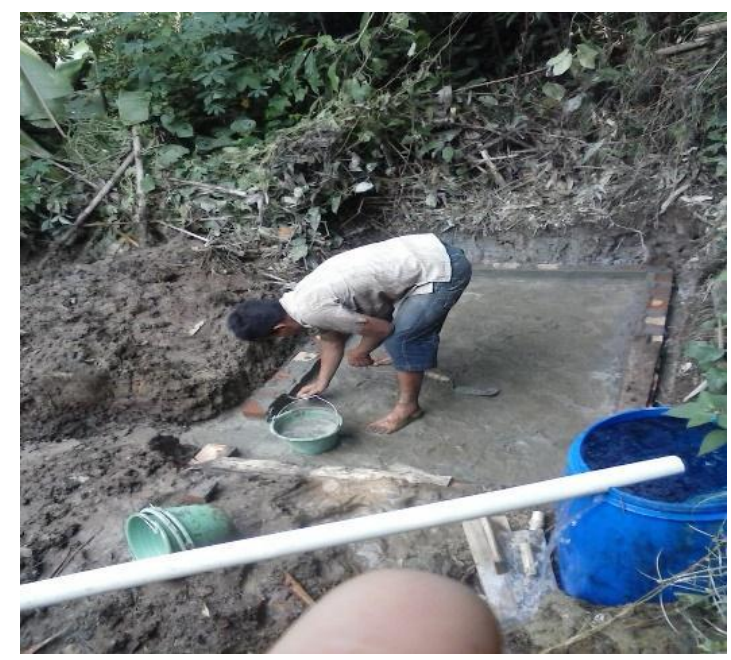

Gambar 3.3. Pembuatan pondasi dan pemasangan tangki penampungan

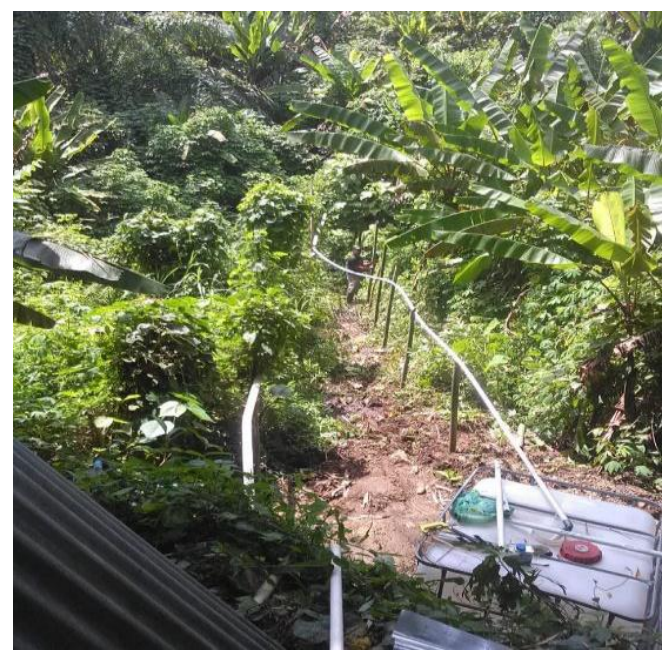

Gambar 3.4. Jalur pemipaan dari sumber mata air ke tangki penampungan 


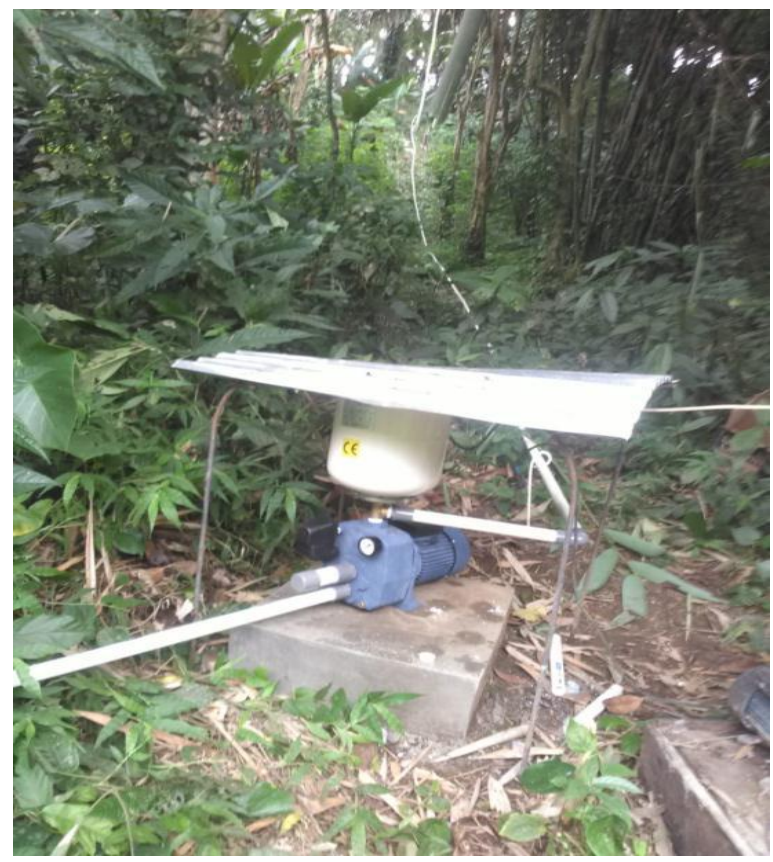

Gambar 3.5. Pembuatan pondasi pompa dan pompa jet pump baru beserta jalur pemipaan

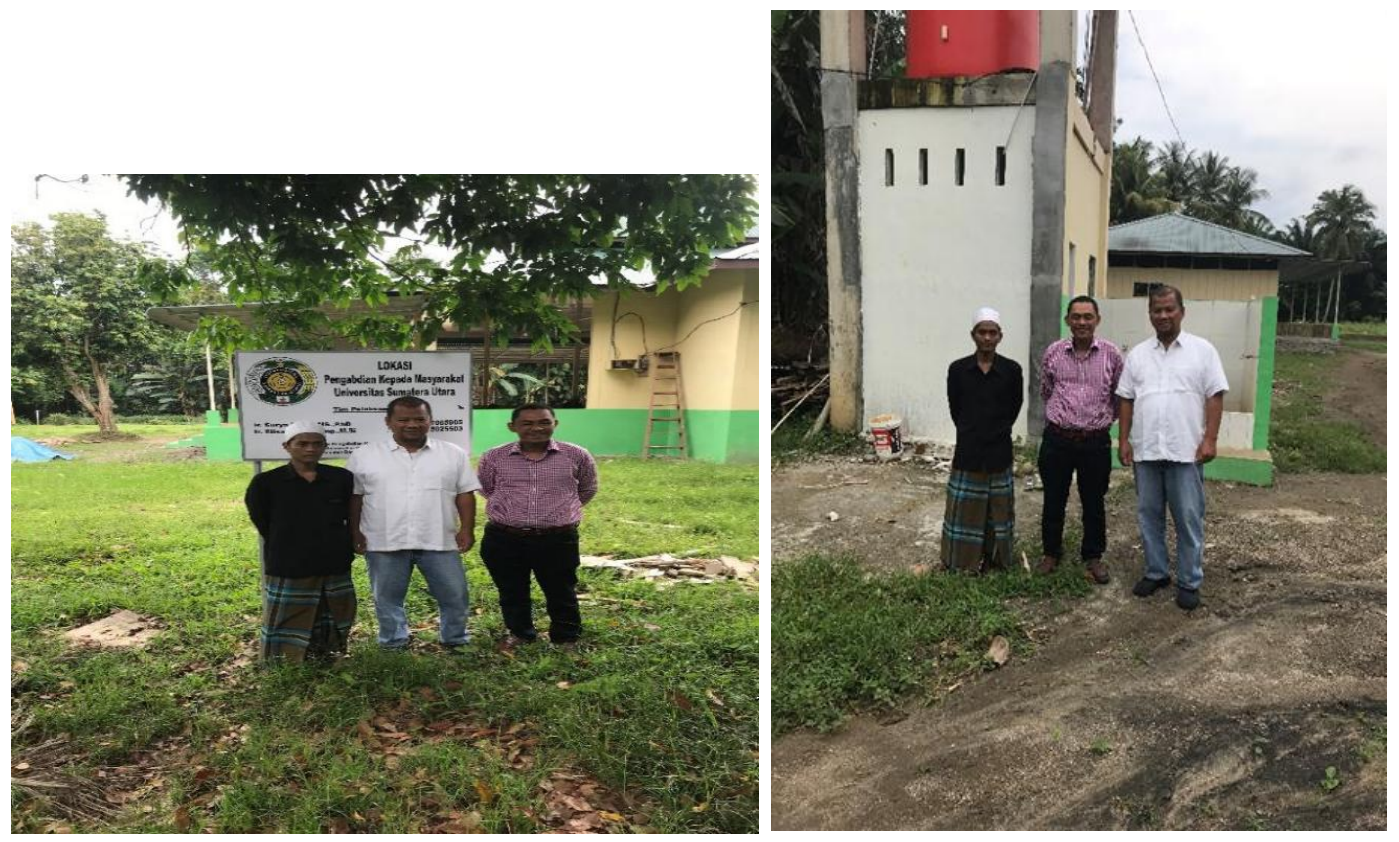

Gambar 3.6. Foto tim pengabdian beserta tim monitoring \& evaluasi dan pengurus pesantren.

Setelah dilakukan pemasangan instalasi pemipaan dan pompa air bersih beserta perlengkapannya maka dilakukan penyuluhan singkat dan padat tentang penggunaan dan perawatan peralatan seperti tersebut di atas. Hal ini dilakukan agar sistem perawatan terhadap fasilitas tersebut dapat maksimal sehingga usia pakai peralatan dapat menjadi lebih lama.

Luaran yang dicapai dari kegiatan pengabdian pada masyarakat ini adalah suatu fasilitas pemipaan dan pompa untuk mengalirkan air bersih yang berasal dari sumber mata air alami ke toren penampungan air yang berjarak \pm 120 meter dan perbedaan ketinggian elevasi 30 meter, yang bertujuan untuk memenuhi kebutuhan air bersih sehari-hari dari sebuah pesantren tahfiz Al-Quran. 
Dengan adanya fasilitas ini, kebutuhan air bersih di pesantren tersebut sangat terbantu sekali karena mereka dapat menggunakan air bersih dengan mudah. Kontribusi mendasar pada khayalak sasaran yaitu memberikan manfaat pada para santri dalam hal pemenuhan kebutuhan air bersih. Secara rinci bantuan yang telah diberikan adalah sebagai berikut :

\section{KESIMPULAN}

Dari kegiatan telah dibuat suatu fasilitas pemipaan dan pompa untuk mengalirkan air bersih yang berasal dari sumber mata air alami ke toren penampungan air yang berjarak \pm 120 meter dan perbedaan ketinggian elevasi 30 meter, beserta perlengkapannya yang sebagai berikut :

a) $1(\mathrm{satu})$ unit pompa air dengan spesifikasi tinggi tekan $($ Head $)=120$ meter dan kapasitas $(\mathrm{Q})=$ 110 liter/menit

b) $1($ satu $)$ unit pompa air dengan spesifikasi tinggi tekan $($ Head $)=33$ meter dan kapasitas $(\mathrm{Q})=$ 28 liter/menit

c) 1(satu) set instalasi kabel listrik dan switch on/off.

d) 1(satu) set instalasi pemipaan dari sumber air ke tangki penampungan ( $\mathrm{L}=120$ meter).

Kemudian kapasitas dan kualitas air yang didapat cukup baik serta layak untuk kebutuhan mandi, cuci, kakus (MCK) untuk 10 orang santri. Telah dilakukan penyuluhan tentang perawatan fasilitas pemipaan dan pompa air bersih yang diikuti para santri di lokasi pengabdian dan kontribusi mendasar pada khayalak sasaran yaitu memberikan manfaat pada para santri dalam hal pemenuhan kebutuhan air bersih.

\section{UCAPAN TERIMAKASIH}

Artikel ini merupakan salah satu hasil dari Program Pengabdian kepada Masyarakat yang dibiayai oleh dana NON PNBP Universitas Sumatera Utara. Oleh karena itu, diucapkan terima kasih kepada Rektor Universitas Sumatera Utara atas dukungan dana dan fasilitas yang diberikan. Terima kasih juga kepada Mitra pada kegiatan pengabdian ini.

\section{DAFTAR PUSTAKA}

Adhyatma, 1990, Daftar Persyaratan Kualitas Air Bersih, Peraturan Menteri Kesehatan R.I.No. : 416/MENKES/PER/IX/1990, September 1990.

Anonimous, 2011, Instalasi Pemipaan Air Bersih, Edisi Desember 2011, Erlangga

Prihatin,R.B., 2013, Problem Air Bersih di Perkotaan, Info Singkat, Pusat Pengkajian, Penglohan Dan dan Informasi (P3DI) Sekretariat Jenderal DPR RI, ISSN 2088-2351, Vol.V No.7, hal.912.

Anonimous, 2007, Medan dalam Angka, Geografism www.pemkomedan.go.id online 13 Oktober 2015.

Anonimous, 2012, Air Bersih, Sanitasi \& Kebersihan, Ringkasan Kajian, UNICEF Indonesia. 